\title{
Seed Ecology of the Invasive Tropical Tree Parkinsonia aculeata
}

\section{Journal Article}

Author(s):

Cochard, R.; Jackes, B.R.

Publication date:

2005-09

Permanent link:

https://doi.org/10.3929/ethz-b-000031224

Rights / license:

In Copyright - Non-Commercial Use Permitted

Originally published in:

Plant Ecology 180(1), https://doi.org/10.1007/s11258-004-2780-4 


\title{
Seed ecology of the invasive tropical tree Parkinsonia aculeata
}

\author{
R. Cochard ${ }^{1, *}$ and B.R. Jackes ${ }^{2}$ \\ ${ }^{1}$ Geobotanical Institute, Swiss Federal Institute of Technology, 8092 Zürich, Switzerland; ${ }^{2}$ Department of \\ Tropical Plant Sciences, James Cook University, Townsville Q4811, Australia; *Author for correspondence \\ (e-mail: roland.cochard@env.ethz.ch)
}

Received 28 January 2004; accepted in revised form 29 August 2004

Key words: Biocontrol, Bruchids, Seed bank dynamics, Seed germination, Invader management

\begin{abstract}
Parkinsonia aculeata is an invasive tree native to tropical America, but introduced to Australia. Propagation and stand regeneration is mainly by seed. To gain baseline knowledge for management decisions, seed bank dynamics were monitored for two months during the fruit dispersal period at a coastal wetland in Costa Rica (native habitat), and at a coastal wetland and two semi-arid rangeland sites in Northern Queensland, Australia (introduced habitats). Seed bank densities underneath dense, uniform Parkinsonia stands were found to be lowest in the Australian wetland but highest in the Costa Rican wetland. Postdispersal seed losses were highest in the Australian wetland, primarily due to seed germination and/or death. At the other sites, seed losses were minor during the study period, and predation was the most important cause of losses. At the two rangeland sites bruchid beetles accounted for more than $95 \%$ of the seed losses by predation. Total predation was lowest in the Costa Rican wetland. In order to test for intrinsic differences of seed characteristics, germination trials were conducted using both canopy seeds and seeds from the soil seed bank. Dormancy release and germination rate were studied under four temperature treatments. In all populations, dormancy release increased with increasing temperature, but averaged responses were significantly different between Costa Rican and Australian seed populations, and between seeds collected from the soil and from trees. Germination rate of scarified seeds was fastest at $35{ }^{\circ} \mathrm{C}$ in all tested seed populations. While high seed germination levels seem to explain low seed bank densities in the Australian wetland, the large seed banks at the rangeland sites reflect the lower incidence of favourable conditions for germination. In the Australian wetland biocontrol with bruchids is unlikely to be successful, while control by conventional methods, such as killing stands by basal bark spraying, seems feasible, due to a lower long-term risk of re-infestation from the soil seed bank. At the rangeland sites conventional control will be difficult and costly. Parkinsonia stands may be better left to their own, while bruchid populations are monitored and management efforts are concentrated on preventing further invasion.
\end{abstract}

\section{Introduction}

The importance of seed ecology and seed bank dynamics in the battle against invasive plants is widely recognised (Lonsdale et al. 1988; Van der Valk and Pederson 1989; Cousens and Mortimer
1995). Factors affecting seed production, dispersal, predation and germination determine spread, recruitment and regeneration in noxious plant populations. After plant eradication, any seeds in the soil may remain a source of re-infestation for many years to come (Cavers and Benoit 1989). 
Yet, seed bank dynamics of many important invasive plants are still poorly studied and most studies have focused on certain aspects of the seeds' life history rather than the overall trends in seed budgets in time and space (Humphries et al. 1991; Grice 1996; Weber 2003). For management of a noxious plant it is, however, necessary to understand its reproduction cycle in order to identify the crucial stages where recruitment success may be limited, and where control measures may be effective. In addition, it is necessary to know variations in the reproduction cycle under different environmental conditions in order to understand why control measures may be effective at one site, but fail at another site (Cousens and Mortimer 1995).

Parkinsonia aculeata L., a spiny, leguminous tree, is native to tropical semi-arid America, but has been introduced to other parts of the world as a resource for wood production in arid regions or as an ornamental and shade tree (Weber 2003). In some countries the plant is still viewed as a potentially useful wood resource (e.g. Zodape 1991; Teketay 1996; Foroughbakhch et al. 2000), but in Australia it has become invasive and is a declared plant (Humphries et al. 1991). Since its introduction in the late 19th century Parkinsonia has spread into many wetlands and along rivers of the dry tropics from Queensland to Western Australia, forming dense thickets and restricting access of stock to drinking water (Woods 1988). In Central Queensland it is a threat to waterbird habitats of national significance (Humphries et al. 1991). Parkinsonia is also becoming a problem in the wetlands of Palo Verde National Park in Costa Rica where the plant is native (Vaughan et al. 1994). Since the early 1980s the centre of Palo Verde Lagoon has been extensively invaded by Parkinsonia thickets. Pods of Parkinsonia are transported on water, and seedling establishment on elevated ground in the lagoon appears to be increasingly successful after introduction of the Eurasian weed Typha dominguensis in the late 1970s (M. Quesada pers. comm.).

In Australia, Parkinsonia was initially controlled by basal bark spraying (Woods 1988). However, the remoteness of many infestations and low land use meant that conventional control was often impractical and uneconomic (Woods 1988). Hence, research has mainly focused on the search for and establishment of a suitable biocontrol agent (e.g. Woods 1988; Donnelly 1994; Flanagan et al. 1996; Briano, et al. 2002). Two American bruchid beetles, which are specific hosts of Parkinsonia seeds, have been released in Australia. Mimosestes ulkei Horn, introduced in 1993 from Arizona, has shown little success in establishment at most release sites (QDNR 1998). Penthobruchus germaini Pic., introduced in 1995 from Argentina, has shown promise as an effective biocontrol agent against Parkinsonia with high reported predation rates (up to $99.5 \%$ seed losses at some sites; QDNR 1998).

If biocontrol with $P$. germaini is indeed almost $100 \%$ effective, then Woods (1985a) has suggested that Parkinsonia stands may be expected to decline naturally over time as a result of insufficient recruitment and natural depletion of the soil seed bank. Clearing may then be counterproductive and a waste of resources as it may trigger the persistent soil seed bank to germinate, enhance seedling growth, and exterminate the bruchid population that mainly depends on the canopy seed pool. Effectiveness of biocontrol is, however, unlikely to be uniform over the distributional range of Parkinsonia. Seed loss to predators has been observed to vary significantly along several climatic and environmental gradients which suggests that predators often contribute to the extensive spatial heterogeneity observed in seed rain and seed banks of many plant species (Louda 1989). Minor changes in temperature can have significant effects on fecundity, longevity, developmental times, survivorship and body size of bruchids (cf. Kistler 1982; Kistler 1995), and therefore indirectly affect the seed bank of the food plant. Seed beetle populations may themselves be controlled by parasitoid wasps (Southgate 1979), whereby the success of these wasp populations and their impact on bruchid populations may again vary along certain gradients (cf. Ouedraogo et al. 1996). An important question for management is whether biocontrol by seed beetles is sufficient alone, or whether it is advisable to continue to control Parkinsonia by mechanical means while the distribution of some infestations is still limited.

According to Johnson and Siemens (1996) Mimosestes spp. only oviposit on pods that are still on the plant, but Traveset (1991a) found that $M$. mimosae and $M$. nubigens also attacked some pods on the ground, even though canopy pods were much preferred. $P$. germaini has been 
observed to oviposit on seed pods on the ground (QDNR 1998) and also on bare seeds in the laboratory (R.C. pers. obs.). Nevertheless, fallen pods may easily escape bruchid detection and infestation. In wetlands, for example, Parkinsonia is often standing in water during the fruit dispersal period, and pods falling into the water may escape infestation, or beetle larvae may be drowned before killing the seed embryos. The rate of seed drop as well as the rate of beetle infestation may therefore influence the success of bruchid biocontrol.

If biocontrol is not effective, then other seed ecological parameters may be more important for management. Seed production with regard to resource availability was explored at Palo Verde by Wyatt (1981). His data showed a lower average seed/pod ratio of Parkinsonia trees growing in a seasonally dry swamp as compared to a nearby wetter swamp, but he did not actually assess total seed production per area. Seed bank densities and field germination rates have not yet been assessed for Parkinsonia (Palmer 1996; A.C. Grice pers. comm., J.S. Vitelli pers. comm.). Laboratory trials showed that Parkinsonia seeds are impermeable to water, and there was no evidence of physiological dormancy (Woods 1988; Everitt 1983; Alvarez Rangel 1984a). Under favourable moist conditions, dormancy of most seeds was broken by long exposure to temperatures between 30 and $45^{\circ} \mathrm{C}$ (Alvarez Rangel 1984b). Reported seed germination percentages of untreated seeds (Mohnot and Chatterji 1965; Everitt 1983; Woods 1988; Alvarez Rangel 1984a; Zodape 1991; Teketay 1996) indicate that seed populations from different regions had different responses to water absorption. Such differences in germination characteristics may be reflected in the soil seed banks of the respective sites, and, consequently, assessment of those differences is primary to any management strategy. Vitelli and Donnelly (1995) noted that clearing of mature Parkinsonia stands hastened seed germination from the soil seed bank, requiring followup control, either mechanically, chemically, or by use of fire. Thus baseline data of seed bank size and seed germination properties from different sites are required in order to understand the effect of tree clearing, and how long it may take to deplete the seed bank.

The aim of this study was to provide important baseline information on Parkinsonia seed bank dynamics, and to demonstrate its relevance to management of this invader. Our main objective was to explore to which degree several ecological factors affect Parkinsonia soil seed bank densities at four contrasting sites, one in the native range in Central America (Palo Verde National Park; a coastal, ephemeral wetland), and three in the new range in North Queensland, Australia (one coastal, ephemeral wetland and two semi-arid rangeland sites). We hypothesised that seed bank densities would differ among sites as a result of the variation of (1) total seed production of Parkinsonia stands, (2) age structure of stands, (3) seed predation rate, (4) seed dispersal rate, (5) seed germination rates in the field, and (6) inherent or induced germination properties of seed populations. A second objective was to estimate and discuss the regeneration potential that may be expected from seed banks after tree clearance. A summary of specific hypotheses is given in Table 1 .

\section{Methods}

\section{Study sites}

Parkinsonia infestations were studied from February to July 1998 in Laguna Palo Verde (PV), the main coastal wetland of Palo Verde National Park, Guanacaste Province, Costa Rica (10.21 N/ 85.17 W; Figure 1). This site was selected as it represented a large, well-known bushland dominated by Parkinsonia (in Spanish: 'palo verde'). In North Queensland, Australia, seed bank dynamics were studied in infestations in the coastal wetland of the Townsville Town Common (TC) Environmental Park (19.22 S/146.76 E; Figure 1). Additional seeds for germination trials and the regression study of tree size against seed bank density were collected in the swamps, $15 \mathrm{~km}$ to the South near the Cluden (CL) Race Track (19.27 S/ 146.86 E; Figure 1). Because of the close proximity of these two sites, the assumption has been made that the seed characteristics would be similar. The two rangeland study sites were located in the Charters Towers region, North Queensland: an extensive infestation along Brigalow Creek near Caerphilly (CA) Cattle Station (21.02 S/146.54 E; Figure 1), and an infestation of a paddock near Eumara Springs (ES) Cattle Station (19.75 S/ 145.96 E; Figure 1). The Australian sites were all monitored from September 1998 to January 1999. 
Table 1. Summary of hypotheses and the respective decisions based on the study results.

\begin{tabular}{|c|c|c|}
\hline \multicolumn{2}{|c|}{ Hypotheses } & \multirow[t]{2}{*}{$\begin{array}{l}\text { Decisions based } \\
\text { on results }\end{array}$} \\
\hline \multicolumn{2}{|c|}{ (1) Seed bank densities and dynamics } & \\
\hline Hla & $\begin{array}{l}\text { There are differences in seed densities of soil seed banks among the four study sites Palo Verde } \\
\text { (PV), Town Common (TC), Eumara Springs (ES) and Caerphilly (CA) }\end{array}$ & Accept \\
\hline$H 1 b$ & $\begin{array}{l}\text { There are differences in seed densities of soil seed banks between Cluden (CL; wetland) and } \\
\text { Caerphilly (rangeland) }\end{array}$ & Accept \\
\hline$H 2$ & Seedling establishment is higher in wetlands (PV, TC) than in rangelands (ES, CA) & Accept \\
\hline$H 3$ & $\begin{array}{l}\text { Seed rain per stand area is higher in the wetlands }(\mathrm{PV}, \mathrm{TC}) \text { than in the rangelands (ES, CA) as a } \\
\text { result of higher seed production in wetlands }\end{array}$ & Reject \\
\hline$H 4 a$ & $\begin{array}{l}\text { Pre-dispersal seed predation is higher in Australia (TC, ES, CA) than in Costa Rica (PV) (e.g. } \\
\text { because populations of } P \text {. germaini have a higher inherent growth potential than populations of } \\
\text { Mimosestes spp.) }\end{array}$ & Accept \\
\hline$H 4 b$ & $\begin{array}{l}\text { Within Australia, pre-dispersal seed predation by } \text { P. germaini is lower at the wetland (TC) than in } \\
\text { the rangelands (ES, CA) (e.g. because of lower beetle population growth resulting from higher } \\
\text { mortality of eggs, larvae and beetles in wetlands) }\end{array}$ & Accept \\
\hline $\mathrm{H} 4 \mathrm{c}$ & $\begin{array}{l}\text { Total seed predation is higher in Australia (TC, ES, CA) than in Costa Rica (PV), since } \\
P . \text { germaini also attacks seed sources that have dropped on the ground }\end{array}$ & Reject at this stage \\
\hline$H 4 d$ & $\begin{array}{l}\text { Predation pressure on beetles by parasitoid wasps is higher in Costa Rica than in Australia (e.g. } \\
\text { because there may be a higher diversity of co-evolved wasps) }\end{array}$ & Reject \\
\hline H5 & $\begin{array}{l}\text { Seeds drop faster in wetlands (PV, TC) than in rangelands (ES, CA) (e.g. because of more wind } \\
\text { and rain) }\end{array}$ & Accept \\
\hline H6 & $\begin{array}{l}\text { Loss of seeds from the soil seed bank is faster in wetlands (PV, TC) than in rangelands (ES, CA), } \\
\text { because of higher rates of water imbibition followed by either germination or death of seeds }\end{array}$ & $\begin{array}{l}\text { Reject in this study } \\
\text { (But possibly accept } \\
\text { for Australia only.) }\end{array}$ \\
\hline$H 7$ & Seed bank densities increase underneath trees with increasing bole size ( $\sim$ age $)$ & Accept \\
\hline$H 8 a$ & $\begin{array}{l}\text { There are differences in germination rates between fresh, untreated seeds of Costa Rican and of } \\
\text { Australian origin (e.g. inherent, genetically determined differences in the seed coat) }\end{array}$ & Accept \\
\hline$H 8 b$ & $\begin{array}{l}\text { In Australia there are differences in germination rates between fresh, untreated seeds from the } \\
\text { wetlands (TC, CL) and rangelands (ES, CA) (e.g. climatically induced differences) }\end{array}$ & Reject \\
\hline$H 8 \mathrm{c}$ & $\begin{array}{l}\text { There are differences in germination rates between untreated fresh CL canopy seeds and older CL } \\
\text { canopy seeds from the previous fruiting season ( canopy hardened seeds) }\end{array}$ & Reject \\
\hline$H 8 d$ & $\begin{array}{l}\text { In Australia there are differences in germination rates of untreated canopy seeds and seeds from } \\
\text { the permanent soil seed bank (e.g. by seed hardening and/or selection in the soil) }\end{array}$ & Accept \\
\hline H8e & $\begin{array}{l}\text { There are inherent differences in germination rates between fresh, scarified seeds of Costa Rican } \\
\text { and of Australian origin (e.g. genetically determined differences) }\end{array}$ & Possibly accept? \\
\hline \multicolumn{3}{|c|}{ (2) Regeneration potential from seed banks } \\
\hline H9 & Optimal germination conditions are above average ambient wet season temperatures & Accept \\
\hline$H 10$ & $\begin{array}{l}\text { Older seeds from the seed bank and previous fruiting season are germinating slower and in lower } \\
\text { percentages than fresh canopy seeds from the current fruiting season }\end{array}$ & Reject \\
\hline
\end{tabular}

Infestations of Parkinsonia at Palo Verde and Town Common were patchy but dense, occurring mainly on elevated ground within the ephemeral wetlands. At Town Common the stands were relatively young in contrast to Cluden where large solitary trees were common and younger stands were rather patchy and small. These large trees were a good source for seeds from the soil seed bank. The infestation at Caerphilly was one of the largest and oldest in North Queensland (P. Jeffrey pers. comm.). Individual Parkinsonia trees up to
$8 \mathrm{~m}$ high were scattered in paddocks and in $\mathrm{Mel}$ aleuca woodland over several square kilometers, with dense stands common along watercourses. The infestation near Eumara Springs was situated in a low-lying paddock close to an ephemeral swamp. Trees were generally small and occurred in more open stands. Soils at all sites were cracking clays, mostly hydrosols or vertisols (Isbell 1993).

Both Palo Verde and North Queensland experience a pronounced wet and dry season. Average monthly rainfall and temperature for all sites are 


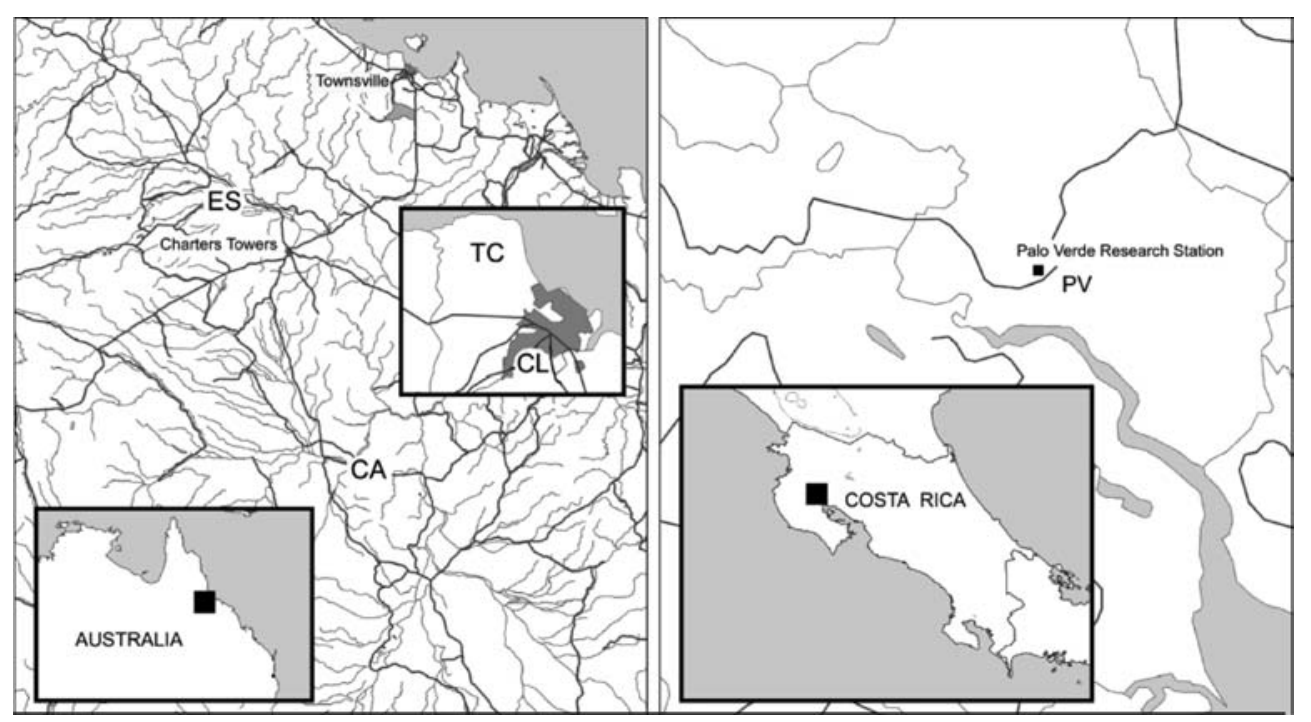

Figure 1. Map of study sites: Location of Palo Verde Lagoon [PV] in Palo Verde National Park, Costa Rica (right), and location of Australian study sites within North Queensland (left): Eumara Springs [ES] and Caerphilly [CA] cattle stations in the Charters Towers region, and the Townsville Town Common Environmental Park [TC] and Cluden [CL] suburb near Townsville.

presented in Table 2. At Palo Verde flowering occurs from December to February and most pods were ripe by the end of February. In North Queensland Parkinsonia flowers from September to October and normally has ripe pods beginning of November but in 1998 seed set was retarded for about 3 weeks, possibly due to unseasonal rainfalls during September/October.

\section{Data collection and analyses}

Soil seed banks, seedling banks and seed rain

Five permanent $10 \times 10 \mathrm{~m}$ study plots were selected at Town Common, Caerphilly, and Eumara Springs, and four at Palo Verde. These plots were set up in Parkinsonia stands with a similar structure, and even density (20-30) of young to

Table 2. Monthly averages of precipitation and temperature (3 p.m.) for the weather stations at Taboga ( $10.21 \mathrm{~N} / 85.09 \mathrm{~W}$; records 1970-1987) close to Palo Verde, Townsville AMO (19.25 S/146.76 E; records 1940-1998), Charters Towers Post Office (20.08 S/146.26 E; records 1882-1998) south of Eumara Springs and Twin Hills Post Office (21.95 S/146.95 E; records 1888-1985) south of Caerphilly.

\begin{tabular}{|c|c|c|c|c|c|c|c|c|}
\hline \multirow[t]{2}{*}{ Month } & \multicolumn{4}{|c|}{ Precipitation $(\mathrm{mm})$} & \multicolumn{4}{|c|}{ Temperature $\left({ }^{\circ} \mathrm{C}\right)$} \\
\hline & PV & TC & ES & CA & PV & $\mathrm{TC}$ & ES & $\mathrm{CA}$ \\
\hline Jan & 1.9 & 268.8 & 136.9 & 119.5 & 26.6 & 29.9 & 32.5 & 33.4 \\
\hline Feb & 11.4 & 282.9 & 130.1 & 114.2 & 27.6 & 29.7 & 31.3 & 32.3 \\
\hline Mar & 9.9 & 195.2 & 103.5 & 71.4 & 28.3 & 29.3 & 30.6 & 31.6 \\
\hline Apr & 45.3 & 63 & 43.4 & 36.8 & 28.8 & 28.1 & 29 & 29.8 \\
\hline May & 233.8 & 35.8 & 24 & 28.5 & 27.7 & 26.2 & 26.3 & 25.8 \\
\hline Jun & 250.6 & 21 & 26.5 & 32.8 & 26.8 & 24.3 & 24 & 23.3 \\
\hline Jul & 128.7 & 14 & 16.8 & 21.7 & 27.2 & 23.7 & 23.8 & 23 \\
\hline Aug & 202.2 & 13.2 & 13 & 15.9 & 26.7 & 24.5 & 25.7 & 25.7 \\
\hline Sep & 296.9 & 10.6 & 14.8 & 18.5 & 26.3 & 26.1 & 28.6 & 28.8 \\
\hline Oct & 321.4 & 24.2 & 22 & 27.9 & 26.4 & 27.8 & 31.4 & 31.7 \\
\hline Nov & 107 & 53.8 & 41.4 & 50.5 & 26.6 & 29.3 & 33.1 & 34 \\
\hline Dec & 14.7 & 126 & 87 & 77.7 & 26.6 & 30 & 33 & 34.3 \\
\hline Mean & 135.3 & 92.4 & 54.95 & 51.3 & 27.1 & 27.4 & 29.1 & 29.5 \\
\hline
\end{tabular}

Sources: SENARA (Servicio National de Aguas, Riego y Avenamiento, Costa Rica) and Australian Bureau of Meteorology (http://www.bom.gov.au). 
medium-aged trees. All plots were situated at least $80 \mathrm{~m}$ apart. Seedlings of Parkinsonia were counted before seed set, 15-22 February 1998 at Palo Verde, and 30 October to 5 November 1998 at the Australian sites, within six random $1 \mathrm{~m}^{2}$ quadrats per plot, all quadrats being at least $2 \mathrm{~m}$ apart. Subsequently $30 \times 30 \mathrm{~cm}$ soil samples to a depth of $4 \mathrm{~cm}$ were extracted at the centre of each quadrat, and Parkinsonia seeds stored in the seed bank were extracted by sieving. The core holes were refilled with soil, and seed traps were placed on the ground in the centre of the quadrats. These traps, with a ground area of $50 \times 50 \mathrm{~cm}$, were made from black, fine nylon netting stapled to a wire frame. Rim height of the traps was $15 \mathrm{~cm}$ except at Town Common, where it was $30 \mathrm{~cm}$ as some plots were partially flooded up to about $10 \mathrm{~cm}$ during the summer rains. The ground nets were covered with some soil and debris to make them look similar to the surrounding ground, so seeds in traps were not visually exposed to predators. The great majority of pods ripened around the same time within each site, and the first ripe pods that were observed dropping to the ground marked the onset of the fruit dispersal period. Seed traps were then surveyed one month after pod maturation (20-26 December 1998 in Australia, 20-22 March 1998 at Palo Verde), and after 2 months (25-27 January 1999 in Australia, 22-26 April 1998 at Palo Verde). 'Potential' seed input into traps (the total number of swellings per pod, i.e. the number of seeds initially produced), and 'actual' seed input (the total of remaining dormant seeds; determined by squeezing and feeling pod swellings and counting naked seeds) were recorded.

\section{Pre-dispersal and post-dispersal seed losses}

In each of the plots 20 pods on each of six random branches were tagged with flagging tape around the onset of the fruit dispersal period, 18-23 November 1998 (15-20 February 1998 at Palo Verde). These branches were examined one and 2 months later and the ratio of dropped pods was recorded. At the same time 20 pods were collected from each of six different random branches per plot. These pods were subsequently examined for predation and other causes of seed loss as were the seeds collected in the seed traps. Causes of seed loss were determined as follows: The number of seeds that had imbibed water and had either germinated or died was recorded (seed traps only).
Traces of seed predation on pods by bruchids, parasitoids, moths and ants were recorded (Table 3 ). In cases where predation signs on pods were not clear, pods were opened and the hole in the seed was examined. Predation traces that could still not be identified for predator were noted as 'unidentifiable predation'. All other types of seed loss (e.g. pod dehiscence) were recorded as 'other seed loss'. At Caerphilly the pods found in seed traps were color marked during the first survey in order to obtain an estimation during the second survey of how many pods may have been attacked on the ground. The methodology that was used to assess predation was efficient in the field, but it is noteworthy that it recorded the final stage of predation only, which is only a fraction of total seed infestation at any point in time (cf. Discussion). The data showed high variance, were not normally distributed, and normality could not be achieved by data transformation. Therefore nonparametric statistical methods, i.e. Kruskal-Wallis tests and post hoc Mann-Whitney tests, were used to analyze for differences among sites.

\section{Relationship between seed bank density and tree size at Cluden and Caerphilly}

At each of the two old infestations at Cluden ('wet climate') and Caerphilly ('dry climate') the bole diameter at $30 \mathrm{~cm}$ height of 22 reproductive, freestanding Parkinsonia trees were measured between 30th October and 3rd November 1998. Underneath each tree four soil samples $(20 \mathrm{~cm} \times 20 \mathrm{~cm}$ to a depth of $4 \mathrm{~cm}$ ) were extracted by spade, systematically situated in the four geographic directions $(\mathrm{N}, \mathrm{W}, \mathrm{S}, \mathrm{E})$ at a distance from the tree bole of about $2 / 3$ of the tree canopy radius. The extracted samples were sieved, seeds collected and pooled for each tree. A regression analysis of seed density against tree bole diameter was performed for each site, and differences between the sites in the slopes and $y$-axis intercepts of the regression lines were determined statistically. Analyses were performed on log-transformed data.

\section{Seed germination characteristics}

Two laboratory experiments were performed on different seed populations. In the first experiment we investigated the ratios of seeds that would break dormancy and germinate under four different temperature treatments $\left(25,30,35\right.$, and $\left.40{ }^{\circ} \mathrm{C}\right)$ during a given period of time (7 days). In the 


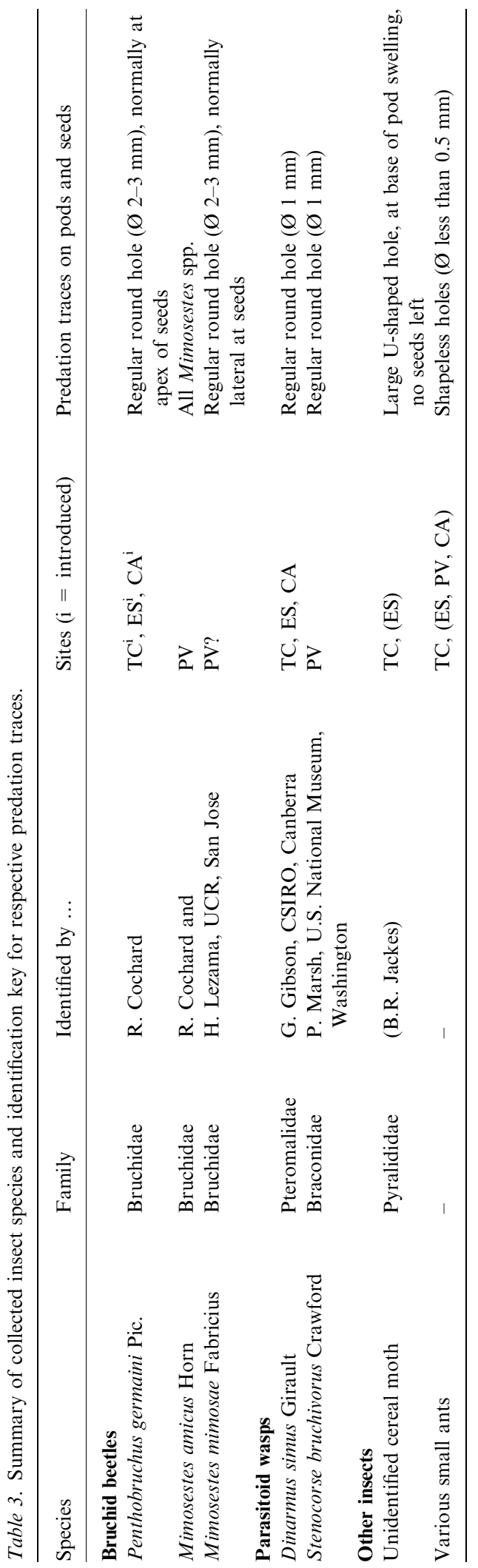

second experiment we investigated the germination rate of scarified seeds under the same temperature treatments. Seeds from the soil seed banks were only collected in sufficient numbers at Cluden and Caerphilly, and sufficient seeds from the previous fruiting season were only found at Cluden. Canopy seed sources of Caerphilly and Eumara Springs were heavily infested with bruchids, making it difficult to obtain clean seeds. For the first experiment seeds were collected from pods on at least 20 trees at each of the five study sites in late November 1998 (April/May 1998 in Palo Verde). Palo Verde and Cluden seeds were also used for the second experiment. Seeds extracted from the seed banks at Cluden and Caerphilly, and seeds collected from underneath four large trees at each site, were used for both experiments. Old seeds from the previous fruiting season (1997/1998) were collected in late October 1998 from trees at Cluden, to check whether older canopy seeds had a lower germination rate and germination vigor and/ or viability than seeds from the current season. All seeds collected from trees were examined under a microscope for evidence of bruchid penetration, and infested seeds were discarded. Before the start of the experiment 100 seeds of each 'site/source' group (source referring to 'on tree', 'on tree 1 year old' and 'in seed bank') were weighed using a microbalance. Twenty seeds from each group were placed in each of six petri dishes (four for Caerphilly/tree and Eumara Springs/tree) filled with water, whereby three petri dish replications (resp. two for Caerphilly/tree and Eumara Springs/tree) were used in each of two experimental replications. Dishes were placed in controlled temperature cabinets at the four temperature treatments for a period of 7 days. Seeds were kept completely submerged during the experiment. Dishes were checked every 12 hours, imbibed seeds were removed and placed on moist filter paper in a fresh petri dish at $30^{\circ} \mathrm{C}$ to test for germinability. After about 3 days imbibed, non-germinated seeds were cut in half and the cotyledons were tested for viability using $1 \%$ 2,3,5-triphenyl tetrazolium chloride (Yu and Wang 1996). The total number of imbibed seeds per dish was recorded after 7 days. For equal sets of data a univariate general factorial analysis of variance was used to detect differences of seed imbibition between temperature treatments, sites and sources, whereby data transformation was not necessary. 
Seeds collected at Palo Verde (source: 'trees'), Cluden ('trees', 'trees, one year old', and 'seed bank'), and Caerphilly ('seed bank') were used for the second experiment. Temperature treatments, cabinets, number of seeds per replicate and number of replications were the same as for the dormancy experiment. Seeds were scarified using fine sand paper, placed into petri dishes and kept completely submerged in water for ten hours under the respective temperature treatment to ensure complete water imbibition by seeds. Subsequently, seeds were taken out of the water and placed on two moist filter papers (water film approximately $1 \mathrm{~mm}$ deep) for germination. Seeds were checked every $6 \mathrm{~h}$. Germination was recorded when the radicle length equalled seed length. Ungerminated seeds were tested for viability as previously outlined. Data were examined statistically for differences in germination proportions among different treatments. Since proportions of germinated seeds were sufficiently high in all petri dishes the mean germination time within each petri dish was used as the dependent variable in the statistical analyses. For equal sets of data a univariate general factorial analysis of variance was used to detect differences in seed germination rate among temperature treatments, sites and sources. SPSS 10 Statistical Software was used for all analyses.

\section{Results}

\section{Soil seed banks, seedling banks and seed rain}

Soil seed densities differed significantly between the sites, and Hla could be accepted (Table 1; Kruskal-Wallis test: $H=36.92, \quad$ df $=3$, $p<0.001)$. Interestingly, median soil seed density was highest at the Costa Rican wetland Palo Verde, but lowest at the Australian wetland Town Common (Figure 2). In contrast, median seedling density was highest at Town Common, and lowest at the two rangeland sites (Figure 2; $H=62.2$, $\mathrm{df}=3, p<0.001)$. The acceptance of $H 2$ is indicated, since most seedlings in Australia established after the exceptional October rains in 1998 which probably provided optimal conditions for germination and growth at all sites (Table 1). Two months after the onset of fruit dispersal 'potential' seed input into the seed traps was not very different among sites (Figure 3; $H=8.10$, df $=3$,

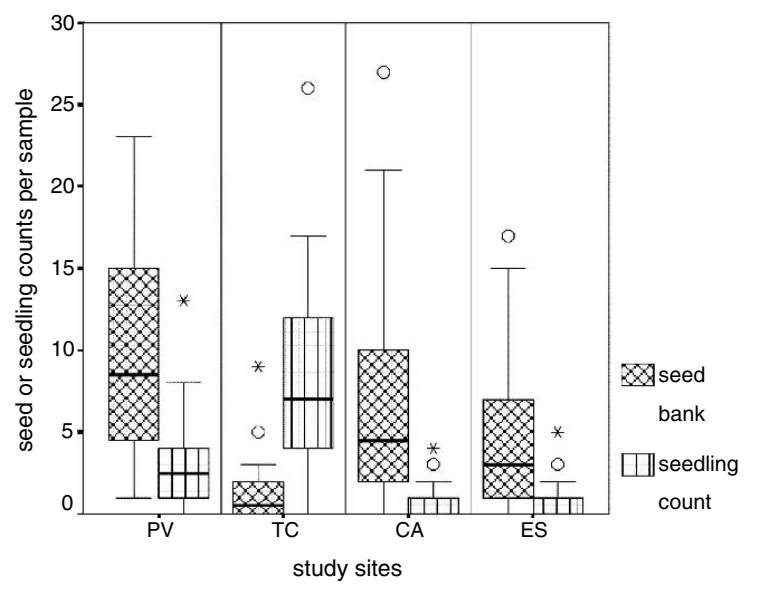

Figure 2. Boxplot graph of seed and seedling counts per sample at the four sites before the fruiting season. Boxplots show the median (central line), interquartile range (box), interdecile range (spikes), outliers (circles; $1.5-3$ box lengths from edge of box), and extreme values (stars; more than 3 box lengths from edge of box).

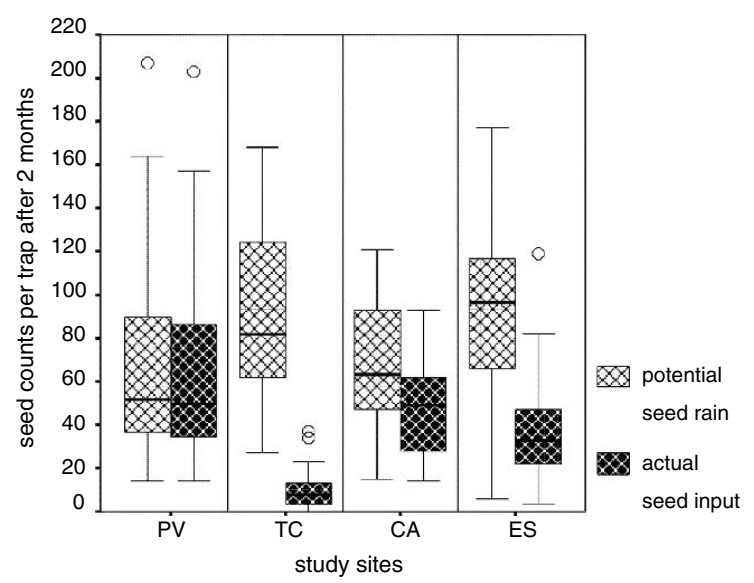

Figure 3. Boxplot graph illustrating sample distributions of actual seed trap input (remaining dormant seeds) and potential seed trap input (number of pod swellings) after 2 months since start of the fruiting season. Explanation for boxplots cf. Figure 2.

$p=0.044)$, and $H 3$ could clearly be rejected since seed rain at rangelands was not lower than at wetlands (Table 1). 'Actual' seed input mirrored, however, the previously observed seed densities in the soil seed bank (Figure 3; $H=56.72$, df $=3$, $p<0.001)$. 


\section{Entomological records}

In Australia, P. germaini was clearly the dominant seed predator of Parkinsonia. No evidence of predation by Mimosestes ulkei was found at the Australian sites. At Palo Verde Mimosestes amicus Horn was collected, but Mimosestes mimosae Fabricius may also occur on Parkinsonia (Table 3). Larvae of a moth often found in cereals were also recorded as a seed predator of Parkinsonia at the Australian sites (Table 3). Stenocorse bruchivorus Crawford was the most common parasitoid at Palo Verde, whereas Dinarmus simus Girault appeared to be the only parasitoid wasp at the Australian study sites (Table 3).

\section{Pre-dispersal and post-dispersal seed losses}

Predation was the most important cause of predispersal seed losses with up to $46 \%$ median seed predation at Caerphilly after 2 months (Figure 4). Lowest predation levels were observed at Palo Verde $(p<0.001$ for all paired site comparisons with Palo Verde), hence $H 4 a$ was accepted (Table 1). Interestingly, median predation levels were highest at Town Common after one month ( $p<0.001$ for all paired comparisons), while increases during the second month were small as compared to the dramatic increases at the two rangeland sites (Figures 4 and 6). On this basis $H 4 b$ was accepted (Table 1 ). In contrast, median predation levels in seed traps after 2 months were below $12 \%$ at all sites (Figure 4). Only 6 new emergence holes of $P$. germaini were counted on the marked pods at Caerphilly. The data, therefore, indicated that, up to this stage of seed dispersal, bruchids had barely attacked pods on the ground, neither in Costa Rica nor in Australia. Pods were infested while on the trees, and beetles emerged before or after pod dispersal. The only proof that $P$. germaini actually uses soil seed sources came from the soil seeds collected before the fruiting season during the tree/seed bank regression study (cf. Methods): bruchids emerged from 12 out of 1318 seeds collected at Caerphilly. Thus at this stage, $H 4 c$ could not be accepted (Table 1).

Bruchids were the most important predators at all sites except Town Common, where moths were equally important (Figure 5). At Town Common (a) Pre-dispersal seed losses after 1 and 2 months

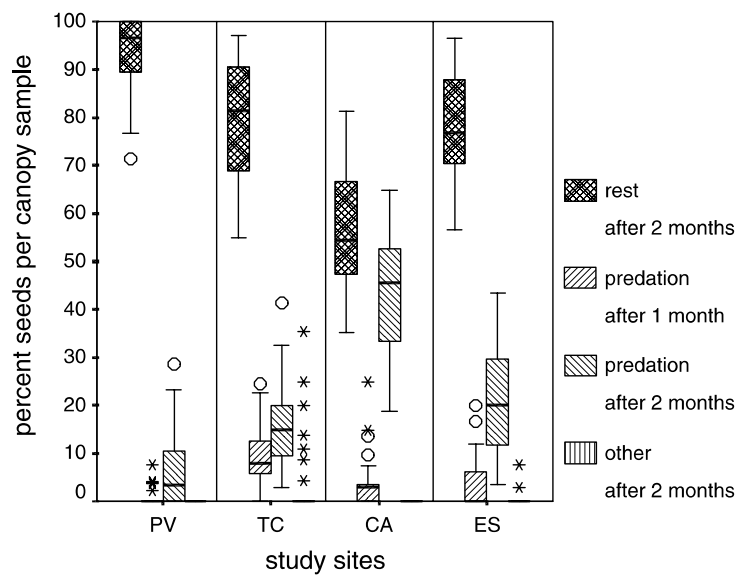

(b) Seed losses recorded from seed traps after 2 months

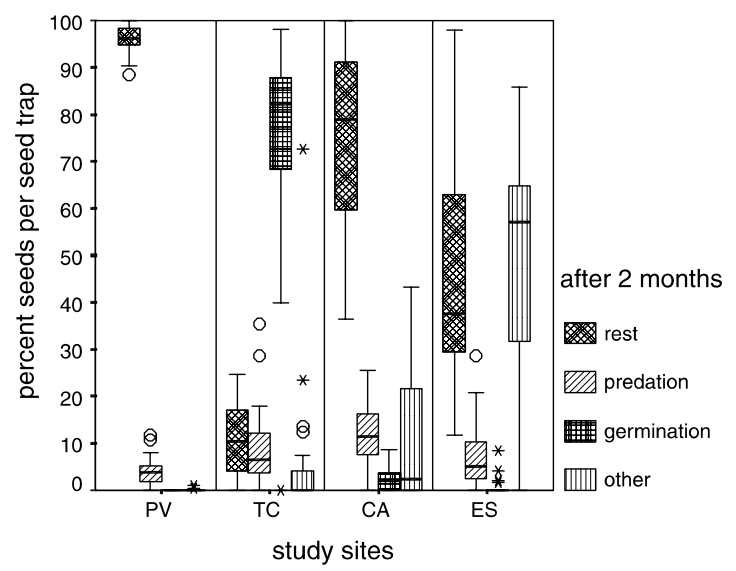

Figure 4. Boxplot graphs illustrating the sample percentage distribution of pre-dispersal (a) and post-dispersal seed losses (b) owing to predation, germination and other factors at the four study sites after two months (incl. pre-dispersal predation after 1 month) since the start of the fruiting season. Explanation for boxplots cf. Figure 2.

many seeds from the tree canopy were, furthermore, observed to be preyed by very small (ca. $1 \mathrm{~mm}$ long) ants (Figure 5, Table 3). Also at Town Common a fair proportion of seeds was lost to unknown predators, possibly large ants, that left a large shapeless hole in the wall of the pods (Figure 5). The parasitoid/bruchid ratios were not statistically different among Palo Verde, Caerphilly and Eumara Springs (pre- and post-dispersal medians: $1 ; H=5.41, \mathrm{df}=2, p=0.067$ ) but highest at Town Common (pre- and post-dispersal medians: $0.5 ; p<0.001$ for all paired 


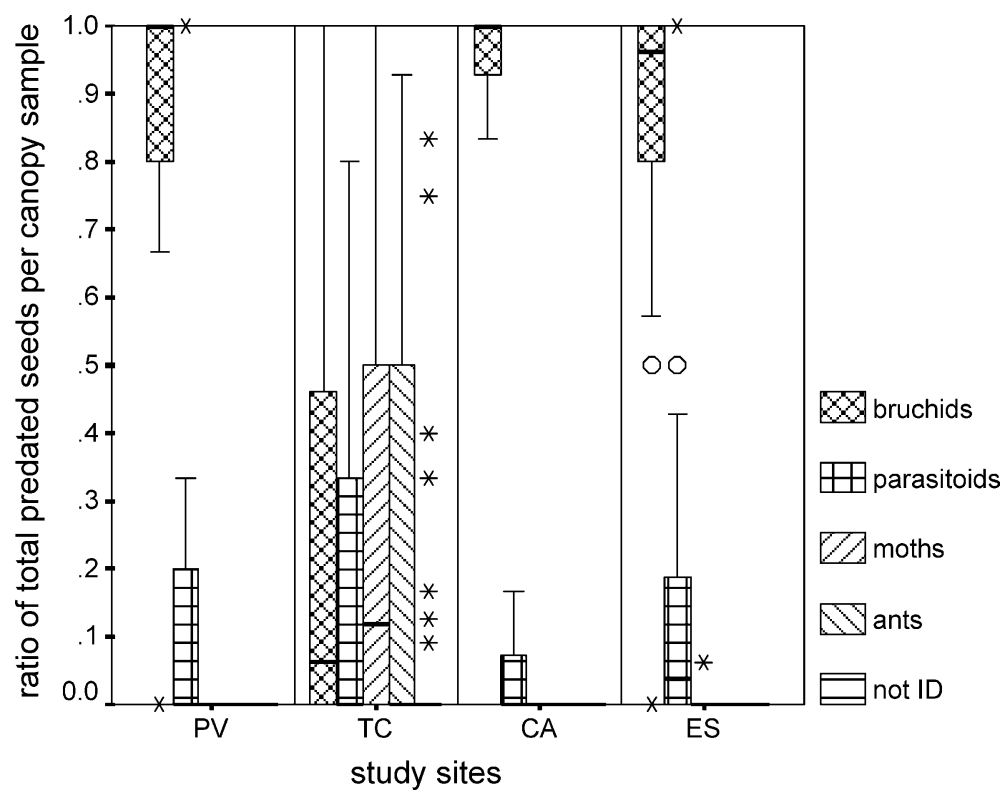

Figure 5. Boxplot graph of the ratios of pre-dispersal predation owing to different predators after 2 months since the start of the fruiting season. Predation ratios recorded from seed traps were similar to pre-dispersal ratios. Explanation for boxplots cf. Figure 2.

comparisons with Town Common). Therefore, $H 4 d$ was rejected (Table 1).

The proportion of fallen pods in the wetlands was significantly higher (Mann-Whitney test: $p<0.001)$ after 1 month as compared to the two rangeland sites, after two months the differences were less marked (Figure 6; $H=11.21$, df $=3$, $p=0.011)$. Therefore, $H 5$ was accepted (Table 1 ).

Two months after the onset of fruit dispersal median percentages of remaining seeds in seed traps were significantly different among sites (Figure 4; $H=93.38$, df $=3, p<0.001$ ). Water imbibition by seeds and subsequent germination or death (most often owing to microbes) was by far the most important factor of seed loss in the wetlands of Town Common, accounting for over $80 \%$ of total losses after 2 months (Figure 4). This seemed to confirm $\mathrm{H} 6$ for Australia where plots at Town Common were at times partially flooded. At Palo Verde it was, however, exceptionally dry with no rain falling during the study period. Hence no seed germination was recorded, and overall $H 6$ could not be accepted during this study (Figure 4, Table 1). At Eumara Springs most losses could not be identified clearly (summarised under 'other loss') (Figure 6). Many pods at this site were dehisced, but very few naked seeds were found in the traps. Seed losses at Palo Verde and Caerphilly were minor and mainly owing to predation (Figure 6).

Relationship between seed bank density and tree age

A regression of seed count (y) against bole diameter $(x)$ was significant at both study sites, Cluden $\left(y=\exp (-7.12+3.23 \ln x)-1 ; R^{2}=0.535\right.$, $p<0.001)$ and Caerphilly $(y=\exp (-7.03+$ 4.14 In $\left.x)-1 ; R^{2}=0.757, p<0.001\right)$. The regression slope was significantly $(t=4.018$, $p<0.001)$ steeper at Caerphilly than at Cluden, while the $y$-axis intercepts of the regression slopes were not different $(t=0.810, p=0.423)$. On this basis $H 7$ and $H 1 b$ were accepted (Table 1 ).

\section{Seed germination characteristics}

Seeds collected from the seed bank were significantly lighter than the corresponding tree seeds at Caerphilly and Eumara Springs (both $p<0.001$ ), and at Town Common $(p=0.005)$, but no significant differences were found at the other two sites (Table 4). Seeds from Palo Verde showed several differences when compared to the seeds 

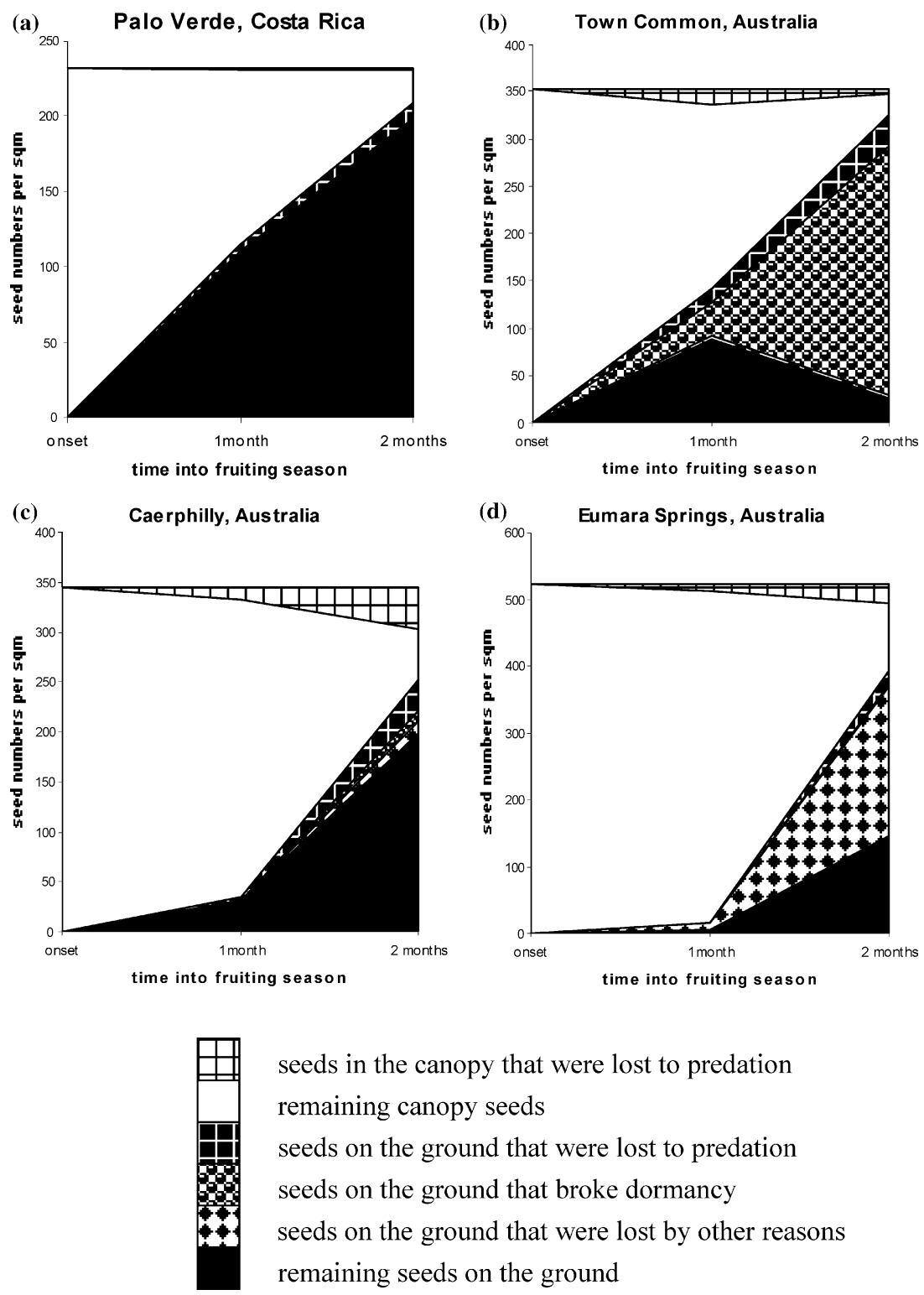

Figure 6. Illustration of trends in estimated seed budgets over the study period at the study sites. Median seed numbers per $\mathrm{m}^{2}$ after 2 months (Figure 4) were supplemented with estimated seed numbers on trees calculated from median ratios of seed drop. From total estimated seed numbers seed loss on the ground and on trees after 1 and 2 months (Figure 5) were calculated.

from Australian sites. They were regularly ovalshaped, rather than pointed at the ends, paler in colour and fresh seeds from the tree canopy also had a lower average seed mass than fresh seeds in Australia (Table 4).

Water imbibition was greater at higher temperatures for all seed samples (Figure 7). The two general univariate factorial ANOVAs revealed significant differences among all factors (tempera- ture, site and source) and interactions ( $p<0.001)$, except for the temperature $\times$ source interaction in the first ANOVA (Cluden and Caerphilly only; $p=0.667$ ). At temperatures above $25{ }^{\circ} \mathrm{C}$, imbibition percentages were statistically similar among the Australian canopy samples (Cluden, Town Common, Caerphilly, Eumara Springs), but significantly lower for the Costa Rican samples (Palo Verde) $(p<0.001$ for all comparisons; Figure 7). 
Table 4. Weights $( \pm \mathrm{SD})$ of seeds from different sites and sources. Mean values followed by a common letter are not significantly $(\alpha=0.05)$ different.

\begin{tabular}{|c|c|c|c|c|}
\hline Site & Source & Mean seed weight (mg) & $\mathrm{SD}(\mathrm{mg})$ & Seed numbers \\
\hline \multirow[t]{2}{*}{ Palo Verde } & Tree canopy & $73.1 \mathrm{e}$ & 9.3 & 100 \\
\hline & Seed bank & $76.7 \mathrm{e}$ & 9.0 & 100 \\
\hline \multirow[t]{2}{*}{ Cluden } & Tree canopy & $93.6 \mathrm{a}, \mathrm{b}$ & 12.4 & 100 \\
\hline & Seed bank & $98.1 \mathrm{a}$ & 11.4 & 100 \\
\hline \multirow[t]{2}{*}{ Town Common } & Tree canopy & $90.9 \mathrm{~b}, \mathrm{c}$ & 11.8 & 100 \\
\hline & Seed bank & $83.7 \mathrm{~d}$ & 9.7 & 26 \\
\hline \multirow[t]{2}{*}{ Caerphilly } & Tree canopy & $83.6 \mathrm{~d}$ & 10.1 & 100 \\
\hline & Seed bank & $66.5 \mathrm{f}$ & 10.7 & 100 \\
\hline \multirow[t]{2}{*}{ Eumara Springs } & Tree canopy & $86.5 \mathrm{c}, \mathrm{d}$ & 9.2 & 100 \\
\hline & Seed bank & $60.2 \mathrm{~g}$ & 11.6 & 110 \\
\hline
\end{tabular}

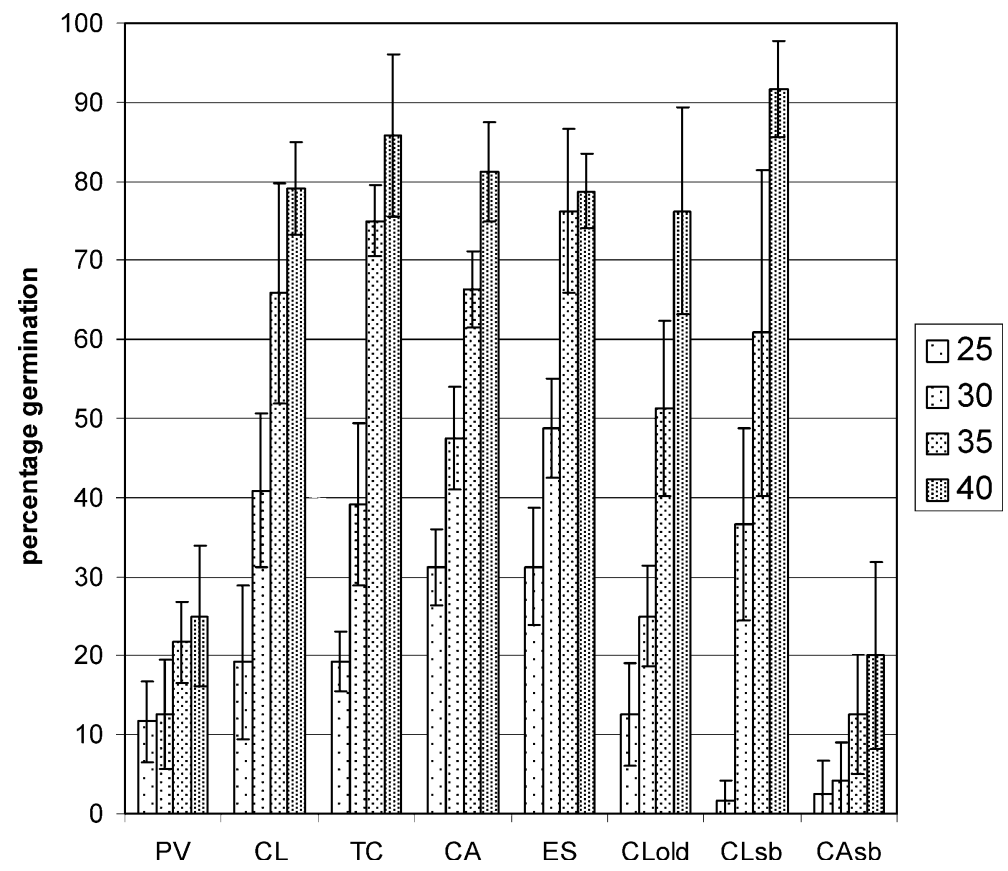

Figure 7. Percentages of dormancy breakage $( \pm$ SD) of seeds after 7 days in water under different temperature treatments $(25,30,35$ and $40{ }^{\circ} \mathrm{C}$ ). Tree canopy seeds from all sites, and seed bank seeds from Cluden (CLsb) and Caerphilly (CAsb) were tested. Additionally canopy seeds from the previous fruiting season were tested for Cluden (CLold).

This supported $H 8 a$, whereas $H 8 b$ was rejected overall (Table 1). Averaged over all temperatures, imbibition percentages of previous season Cluden seeds and newly harvested Cluden seeds were not statistically different $(p=0.787)$, and $H 8 c$ was rejected (Table 1). At $25^{\circ} \mathrm{C}$ imbibition percentages were significantly $(p<0.001)$ lower in soil seed samples than in corresponding tree seed samples at both Cluden and Caerphilly. At higher temperatures, however, imbibition percentages of the Cluden soil seed samples were similar to that of all the Australian tree seed samples, whereas imbibition percentages remained significantly lower ( $p<0.001$ for all comparisons) in the Caerphilly soil seed samples (Figure 7). Hence $H 8 d$ was accepted, noting the interactions: if considering soil seed sources, $H 8 b$ may be accepted (Table 1). Over $90 \%$ of the seeds that imbibed water also germinated and viability tests of nongerminated seeds were negative. 


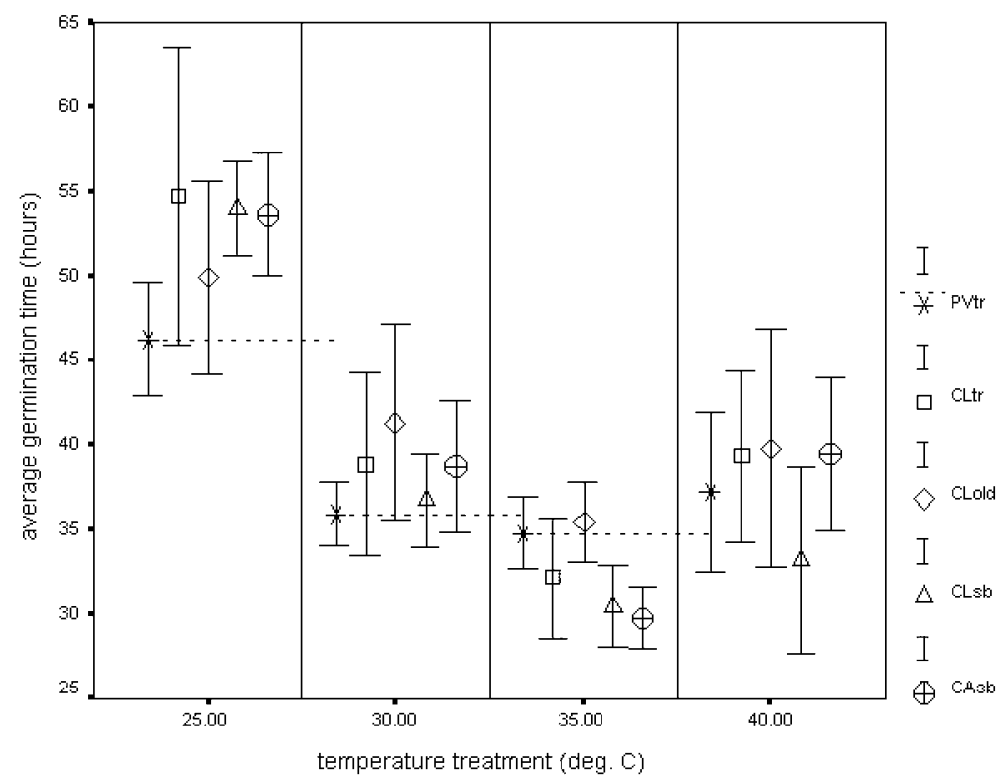

Figure 8. Mean germination times $( \pm \mathrm{SD})$ of different seed populations submitted to four different temperatures. Tree canopy seeds from Palo Verde (PV), Cluden (CL), previous-season tree canopy seeds from Cluden (CLold), and seed bank seeds from Cluden (CLsb) and Caerphilly (CAsb) were tested.

Percentage germination of scarified seeds was on average above $90 \%$ and was not affected by the factors temperature, site or source. Viability tests of non-germinated seeds were mostly negative. Temperature had, however, a significant effect on germination times of all samples $(p<0.001)$, whereby optimal germination temperature was $35{ }^{\circ} \mathrm{C}$ for all samples tested (Figure 8). So $H 9$ could be accepted (Table 1). H10 had to be rejected, since Cluden and Caerphilly soil seeds germinated at similar velocities than Cluden fresh and old canopy seeds (Table 1, Figure 8). There was a significant site difference $(p=0.045)$ and site $\times$ temperature interaction $(p=0.044)$ for the analysis of fresh canopy seeds from Palo Verde and from Cluden. This indicates possible acceptance of $H 8 e$, even though the differences are weak and arguable (Table 1).

\section{Discussion}

\section{Seed banks and seed losses}

Median soil seed densities of the even-structured Parkinsonia stands may be calculated to be about 100 seeds $\mathrm{m}^{-2}$ in the stands at Palo Verde,
5.6 seeds $\mathrm{m}^{-2}$ at Town Common, 50 seeds $\mathrm{m}^{-2}$ at Caerphilly and 33.3 seeds $\mathrm{m}^{-2}$ at Eumara Springs. Those densities were considerably lower than average seed densities observed for some other invasive woody legumes, e.g. in Australia 850012,000 seeds $\mathrm{m}^{-2}$ for exotic Mimosa pigra (Lonsdale 1988), in South Africa about 200048,000 seeds $\mathrm{m}^{-2}$ for introduced Acacia saligna and Acacia cyclops (Holmes 1987), and 600032,000 seeds $\mathrm{m}^{-2}$ for Acacia tortilis (Witkowski 2000), and in Ethiopia $1700-1900$ seeds $\mathrm{m}^{-2}$ for Acacia nilotica (Argaw 1999). As was demonstrated, seed numbers increase exponentially with increasing tree bole (H7), and seed bank comparisons with other leguminous trees are not always straightforward. Yet it is clear that rate of soil seed accumulation is lower for Parkinsonia because of lower seed production per stand area and a higher rate of seed loss. This apparently does not entail a lower invasive potential, since Parkinsonia is in the league of the most noxious woody plants (Humphries et al. 1991).

Seed banks are mainly explained by the specific germination properties of the local seed populations $(H 8)$ in combination with the prevailing climate and other site conditions. Over $80 \%$ of seeds were lost by germination/decay at Town Common, 
which clearly explains the marked differences in the seed bank to the other sites (Figure 6). In normal years germination may also be a significant factor of seed loss at Palo Verde, but germination rate will certainly be lower than at Town Common, in accordance with laboratory results and seed bank observations (Figures 7 and 1). Equally, the low seedling numbers at the rangeland sites after the rains in October 1998 (H2; Figure 2) seem to reflect the comparatively low germinability of seeds in the soil (Figure 7). Seed production did not vary markedly among sites (Figure $3 ; \mathrm{H3}$ ), and seed predation only had a minor impact on the total seed budgets during the study periods (Figure 6).

\section{Intrinsic characteristics of seed populations}

Seed size and mass are highly heritable characteristics and there is a general tendency for increase in size under increasingly drier environmental conditions (Baker 1972). This tendency may hold for the Americas with very large seeds (average of 153-161 mg) recorded from the Sonoran desert of Arizona (Woods 1988), smaller seeds (average of $98.6 \mathrm{mg}$ ) from Maracay, Venezuela (Alvarez Rangel 1984a), and the smallest seeds in the wetlands of Palo Verde (73-77 mg; Table 4). Our data suggest, however, that selection pressures within Australia may have been different and more shortterm. Baker (1972) also found that shading and competitive stress are influential factors in promoting increased mean seed weight, particularly for shrub species, which may explain large seed sizes recorded at the two Townsville sites (Table 4).

The observation that Palo Verde seeds tended to be more spherical in shape and smaller than Australian seeds indicates that parental, genetically controlled effects may be important in explaining the differences in seed permeability. Imbibed seeds of Parkinsonia can still germinate after at least 3 weeks of submersion in water (R.C. pers. obs.). Parkinsonia stands at Palo Verde set seed at the beginning of the dry season (JanuaryFebruary), normally several weeks before the Palo Verde Lagoon, inundated by the Tempisque River, dries out in about January-March. Seeds that break dormancy quickly may, therefore, have less chance of survival, and selection will favour a genotype with low permeability. In North Queensland, pods are ripe at the beginning of the wet season (October-December). Parkinsonia has invaded Town Common in much more recent times. Given that the wet season is shorter at Town Common, and the wetlands are only partially inundated, seeds that germinate immediately may also have an equal or better chance of producing a plant than seeds that remain dormant. Thus, selection will not favour hardseededness.

Very few seeds from the Cluden and Caerphilly soil seed bank germinated at $25^{\circ} \mathrm{C}$, while approximately a fifth of Cluden and a third of Caerphilly tree seeds germinated during the first experiment (Figure 7). It is possible that dropped permeable seeds will be lost from the seed bank by early germination. This explanation may be important at Cluden, since seed permeability between tree seeds from the present fruiting season and from the previous season was not markedly different (Figure 7; H8c). At Caerphilly another explanation is obviously more important: Secondary dormancy of permeable Parkinsonia seeds can be induced under conditions of low humidity and warm temperatures $\left(31^{\circ} \pm 10{ }^{\circ} \mathrm{C}\right.$ ) (Alvarez Rangel 1984b). Soil seeds at Caerphilly were lighter than tree seeds and pale coloured, possibly indicating long exposures of seeds to hot and dry environmental conditions.

The results of the second experiment generally agree with the findings of Alvarez Rangel (1984b), Everitt (1983) and Teketay (1996). In contrast to the Australian seed populations, germination times of Palo Verde seeds were, however, not statistically different between 30 and $40^{\circ} \mathrm{C}$, and mean germination time was lowest for Palo Verde seeds at $25{ }^{\circ} \mathrm{C}$ (Figure 8 ). This may be explained by climatic differences between the Australian sites and Palo Verde. At the Australian sites average daily temperatures peak during the wet season (Table 2). Average daily temperatures at Palo Verde, on the other hand, are more uniform throughout the year $\left(26-29^{\circ} \mathrm{C}\right)$ and peak in April in the late dry season (Table 2). At Palo Verde favourable conditions for germination may, therefore, coincide with a broader range of temperatures which is reflected in a less pronounced temperature response of seed germination than at the Australian sites. 


\section{The impact of seed beetles for biocontrol}

Seed beetles had a minor impact at Town Common and in the native range at Palo Verde, and also for Eumara Springs and Caerphilly percentages of seed predation (Figure 4) were considerably lower than figures presented by QDNR (1998). In contrast to our study, which recorded insect emergence holes (i.e. the final predation stage), QDNR (1998) measured the total infestation ratio. It takes $30-40$ days from oviposition to adult emergence of $P$. germaini (Briano 2002), and 45-60 days of Mimosestes ulkei (Woods 1985b). Consequently, higher seed ratios were already infested than were recorded. Nevertheless, considering that during this study seed beetles attacked almost exclusively canopy seed sources, and also considering the observed rate of predation increase from the first to the second sampling date (Figure 6), total infestation after 2 months was probably below $50 \%$ at Caerphilly and Eumara Springs, and below $15 \%$ at Town Common and Palo Verde. With a rapid depletion of the canopy seed bank, along with a dramatic build-up of the bruchid population, predation of seed sources on the ground could become increasingly important throughout the year. Evidently, $P$. germaini does oviposit on seeds that are exposed on the ground, even if canopy seed sources are much preferred earlier in the season. It is likely that beetle populations profit from the large seed banks underneath large trees at Caerphilly during the late dry season. This may explain differences in predation rate between Caerphilly and Eumara Springs (Figure 4): both sites are climatically not very different, but the infestation at Eumara Springs is smaller and there are no large trees with large seed banks. It can therefore be assumed that there is already a larger bruchid population at Caerphilly at the start of the fruiting season that can multiply faster. For those reasons, biocontrol may be efficient at a site like Caerphilly. With regard to management the question remains, whether seeds that escaped predation in the canopy, will also escape predation on the ground. This may depend on several factors like timing and amount of precipitation. A long-term monitoring programme that also focuses on predation later in the year will be necessary to answer these questions.

The poor performance of bruchid populations at the wetlands (Figures 4 and 5) is mainly explained by a low reproductive success and a low population growth rate during fruit dispersal time (Figure 6). Reproductive success of seed beetles is not only reduced by mortality of beetles and larvae (e.g. by drowning and parasitism). Loss of bruchid eggs by predation or by physical factors (e.g. high rainfall) can be equally important. Traveset (1991b), for example, reported about $50 \%$ ant predation and $30 \%$ other loss of bruchid eggs on Acacia farnesiana in Costa Rica. There were clearly many ants at Town Common, which also had a direct impact on the seed budget of Parkinsonia (Figure 5). The low accessibility and availability (at Town Common) of soil seed sources during the late dry season may also limit success of bruchid populations in wetlands, where seeds are virtually buried in wet mud. Bruchid predation after 1 month was, however, similar between Town Common and the rangeland sites (Figures 4 and 5).

At Palo Verde pods on the ground were not attacked by the native Mimosestes spp. (c.f. Introduction), and given that almost $50 \%$ of seeds after one month and $90 \%$ after 2 months had dropped from trees many seeds escaped predation (Figure 6). Seed drop was slower at the two rangeland sites than in the two wetlands, making it easier for $P$. germaini to exploit seed sources and increase in population size (Figure 6). M. ulkei was no longer recorded during this study, while it was still found at Town Common in 1997/1998 (C. Lockett, pers. comm.). It was probably outcompeted by $P$. germaini. That it survived longest at Town Common indicates, that its reliance on canopy seeds was its disadvantage. It is notable that in October before the new fruiting season, canopy seeds were found only at Cluden (and a few at Town Common), but virtually all seeds were consumed at Caerphilly and Eumara Springs, even though more pods were hanging on trees. Correspondingly, the native Australian moths which also seemed to depend on canopy seed sources were only found in significant numbers at Town Common (Figure 5). There may be an evolutionary explanation for the fact that Mimosestes spp. almost exclusively use canopy seed sources. Reproductive investment in seed sources on the ground may be too much at risk from flooding at wetland sites. P. germaini is native to semi-arid parts of Argentina (Briano 2002) where risk of flooding is probably less eminent. Thus using soil 
seed sources, particularly during the dry season, could be an adaptive advantage.

In comparison to Town Common, parasitoids were not prominent during the study period at Palo Verde, Caerphilly and Eumara Springs (Figure 5). Predation pressure on bruchids by parasitoids may increase later in the year, after a build-up of the parasitoid population. It is, however, unknown whether $D$. simus and S. bruchivorus oviposit on infested seeds on the ground. Urosigalphus sp., a parasitoid of M. mimosae, was observed to oviposit on pods on the ground, but infested pods in the canopy were much preferred (Traveset 1991a). D. simus is a native Australian species that parasitises several native bruchid species (G. Donnelly, pers. comm.). Its population dynamics will also be influenced by bruchid population dynamics of other leguminous plants that occur in the area. Three parasitoid spp. of $P$. germaini were recorded by Briano (2002) in Argentina, which accounted for less than $5 \%$ of parasitism rate. This rate is clearly lower than parasitism at Town Common (ca. 39\%), but similar to the other sites (ca. 4-12\%) (Figure 5).

The causes of almost 50\% seed loss at Eumara Springs were unclear (Figure 4). The proportion of pods that dehisced was high at this dry and open site. Numerous seeds seemed to have fallen from the pods as large numbers of empty, dehisced pods, and husks of destroyed seeds were recorded in the seed traps. Possibly seeds that dropped onto the ground may have been cleaned up by ants. It is likely that a certain proportion of seed predation by $P$. germaini at Eumara Springs remained undetected and was recorded as 'other seed loss'.

Consequences for management and suggestions for further studies

Seeds from the seed bank will be triggered to germinate under favourable, wet conditions, particularly after vegetation clearance when soil temperatures have increased. Suitable wet conditions are less frequent at the rangeland sites than in wetlands (Table 2). Furthermore, at temperatures higher than $25^{\circ} \mathrm{C}$, release of dormancy was considerably quicker for soil seeds collected at Cluden (wetland) than for those collected at Caerphilly (rangeland) (Figure 7). Thus depletion of the seed bank after vegetation clearance would be much faster at the Townsville sites than at the Charters Towers sites, where seeds will be lost slowly from an already very large seed bank (Figure 2). Consequently, the potential for conventional control of Parkinsonia by spraying appears to be considerably higher for the Townsville wetlands. It may be expected that large numbers of seedlings would germinate within one or two years of the vegetation being cleared, necessitating follow-up treatments of seedlings with herbicides or the use of fire. Two to three years after these treatments it should be possible to target seedlings individually. Greatest reduction in seed banks after vegetation clearance was, for example, observed within 1-2 years in the case of Acacia cyclops, whereas post-clearance seed banks declined at a constant yearly rate of $12 \%$ in the case of Acacia saligna (Holmes 1987). Laboratory germination rates of untreated $A$. cyclops seeds were three times those of $A$. saligna (Holmes 1987). The use of postclearance fire appears to be an effective management tool to reduce the seed bank of invasive woody legumes. Up to $95 \%$ of seeds germinated or died after fire in the seed banks of $A$. saligna (Holmes 1988), and over 70\% in the seed banks of Acacia longifolia (Pieterse and Cairns 1986). In a field experiment by Woods (1988), all Parkinsonia seeds were killed by fire on the ground surface, but seeds buried at $2 \mathrm{~cm}$ depth were not affected.

The knowledge that a much larger seed bank can be found underneath older trees may have important implications, since the risk of re-infestation from the seed bank is higher and exists for longer from underneath larger trees. Seed rain as measured per unit area may, however, be similar from younger Parkinsonia stands. In situations where management resources are limited it may, therefore, be sensible first to target younger trees that still have a low and 'manageable' seed bank. Single trees and small outlying stands should be targeted first, since, as illustrated by Moody and Mack (1988), it is these outliers that contribute most to the spread of plant invasives.

Conventional control of Parkinsonia at a site like Caerphilly, where a massive seed bank is present, seems unfeasible with limited resources. Efforts need to concentrate on containing the spread of the invader into un-infested areas. Management by improved pastures may be effective during most years away from waterways (Vitelli and Donnelly 1995). At Caerphilly it would 
be unwise to eradicate Parkinsonia using conventional means. Not only would this lead to a costly, long-term re-infestation problem, but it would probably also affect the bruchid population, that now seems to thrive from an abundance of seeds at this site.

It is possible that $P$. germaini populations will at least slow down the spread of Parkinsonia in the drier regions of its range in Australia, even though its impact may have been over-estimated. As mentioned earlier, a longer-term study should investigate post-dispersal seed predation later in the season, to give reliable estimates of total yearly predation losses by bruchids. Population dynamics should also be monitored over several years, whereby management efforts and monitoring programmes should be closely linked. As $P$. germaini was released in Australia in 1995, it was, presumably, too early to observe any impact on the soil seed banks. Later surveys of seed bank densities at sites like Caerphilly may yield different results.

While biocontrol shows some promise for limited success at Caerphilly and Eumara Springs, it would be naïve to rely on it at Town Common, where Parkinsonia infestations have been spreading rapidly in the past few years. Quick action by conventional means is appropriate when the infestations are still small and seed banks low. A similar recommendation may be given regarding the situation in the Palo Verde Lagoon, although the seed bank can be expected to be more durable than at Town Common. At Palo Verde, eradication of Parkinsonia is more complex since its invasion into the wetlands follows the invasion of the Eurasian weed Typha dominguensis (cattail). McCoy and Rodriguez (1994) considered that the cattail invasion of the Palo Verde Lagoon resulted from the elimination of cattle from the lagoon after National Park declaration in 1980. It has, on the other hand, been suggested (M. Quesada, pers. comm.) that hydrologic changes in the lagoon are implicated, which are ultimately traceable to increased water withdrawal from the Tempisque River for use in upstream paddy fields.

Our study was conducted during only one year. It is, however, well known that particularly insect populations can vary considerably with time (Cappucino and Price 1995). For example, in Botswana bruchid infestation levels on Acacia nilotica varied from $61 \%$ in 1983 to only $7.6 \%$ in
1988, on Acacia tortilis from $48 \%$ in 1987 to $11.9 \%$ in 1988 (Ernst 1990), on Acacia tortilis in the Serengeti apparently even from 74 to $99.6 \%$ in the early 1970s to only 5\% in 1980 (Midgley and Bond 2001). These studies, however, reported only on infestation levels. Any bruchid monitoring programme that is actually designed to determine and quantify the causes of population variation in space and in time could contribute greatly to scientific understanding of bruchid population dynamics and interactions with their host plant.

\section{Acknowledgements}

We are most indepted for the great support of friends in field work and lab preparations, notably Daniello Cuda, Aung Si and Delilah Katz. Joe Vitelli, Catherine Lockett and Peter Jeffrey from the Tropical Weeds Research Centre (TWCR) at Charters Towers provided first hand advice and made us feel at home during stop-overs at TWCR. Thanks for their support also go to Phillippe Hensel and Eugenio Gonzalez at the Palo Verde Research Station in Costa Rica. At James Cook University, Joe Holtum, Jack Christopher and Ross Coventry gave valuable professional advice regarding seed physiology and seed bank ecology, and Ewald Weber and Dominik Brem from the Geobotanical Institute, Zürich, made constructive comments on the manuscript.

\section{References}

Alvarez Rangel R.A. 1984a. Caracterizaciòn de los mecanismos de control de la latencia y germinaciòn de las semillas de Parkinsonia aculeata L. 1. Respuestas de las semillas a los tratamientos para romper la latencia y sus implicaciones ecologicas. Revista de la Facultad de Agronomì (Maracay, Unversidad Central de Venezuela) 8: 5-30.

Alvarez Rangel R.A. 1984b. Caracterizaciòn de los mecanismos de control de la latencia y la germinaciòn de las semillas de Parkinsonia aculeata L. 2. Respuestas de las semillas a algunos factores ambientales y sus implicaciones ecologicas. Revista de la Facultad de Agronomìa (Maracay, Unversidad Central de Venezuela) 8: 31-45.

Argaw M., Teketay D. and Olsson M. 1999. Soil seed flora, germination and regeneration pattern of woody species in an Acacia woodland of the Rift Valley in Ethiopia. J. Arid Environ. 43: 411-435.

Baker H.O. 1972. Seed weight in relation to environmental conditions in California. Ecology 53: 997-1010. 
Briano J.A., Cordo H.A. and Deloach C.J. 2002. Biology and field observations of Penthobruchus germaini (Coleoptera: Bruchidae), a biological control agent for Parkinsonia aculeata (Caesalpiniaceae). Biol. Control 24: 292-299.

Cappuccino N. and Price P.W. 1995. Population Dynamics: New Approaches and Synthesis. Academic Press Inc., San Diego.

Cavers P.B. and Benoit D.L. 1989. Seed banks in arable land. In: Leck M.A., Parker V.T. and Simpson R.L. (eds), Ecology of Soil Seed Banks. Academic Press Inc, San Diego, pp. 309-328.

Cousens R. and Mortimer M. 1995. Dynamics of Weed Populations. Cambridge University Press, Cambridge.

Donnelly G. 1994. Proposal for the field release of the seed beetle Penthobruchus germaini for the biocontrol of Parkinsonia. Unpublished Report, Alan Fletcher Research Station, Department of Lands, Queensland.

Ernst W.H.O., Decelle J.E. and Tolsma D.J. 1990. Predispersal seed predation in native leguminous shrubs and trees in savannas of southern Botswana. Afr. J. Ecol. 28: 45-54.

Everitt J.H. 1983. Seed germination characteristics of two woody legumes (Retama and Twisted Acacia) from South Texas. J. Range Manage. 36: 411-414.

Flanagan G.J., van Rangelrooy D.S. and Kerin S. 1996. Integrated management of Parkinsonia aculeata on the Roper River, Northern Territory, Australia. In: Moran V.C. and Hoffmann J.H. (eds), Proceedings of the IX International Symposium on Biological Control of Weeds, 19-26 January 1996. Stellenbosch, University of Cape Town, South Africa, pp. 441-443.

Foroughbakhch R., Hauad L.A., Maiti R.K., Rodriguez M., Hernandez-Pinero J., Badii M.H., Cespedes A.E. and PonceMoreno E.E. 2000. Techniques of germination and growth potential of some fuelwood species in northeastern Mexico. Phyton 69: 17-22.

Grize A.C. 1996. Seed production, dispersal and germination in Cryptostegia grandiflora and Ziziphus mauritiana, two invasive shrubs in tropical woodlands of Northern Australia. Aust. J. Ecol. 21: 324-331.

Holmes P.M., MacDonald A.W. and Juritz J. 1987. Effects of clearing treatment on seed banks of the alien invasive shrubs Acacia saligna and Acacia cyclops in the southern and south-western Cape, South Africa. J. Appl. Ecol. 24: 1045-1051.

Holmes P.M. 1988. Implications of alien Acacia seed bank viability and germination for clearing. S. Afr. J. Bot. 54: 281-284.

Humphries S.E., Groves R.H., Mitchell D.S., Hallegraeff G.M. and Clark J. 1991. Plant Invasions: The Incidence of Environmental Weeds in Australia. Australian National Parks and Wildlife Service, Canberra.

Isbell R.F. 1993. A classification system for Australian soils (Third approximation). CSIRO Division of Soils. CSIRO Division of Soils. Technical Report 2/1993. CSIRO, Australia.

Johnson C.D. and Siemens D.H. 1996. Oviposition behavior, guilds, distribution and new host records for the genus $\mathrm{Mi}$ mosestes Bridwell (Coleoptera: Bruchidae) from Colombia, Ecuador, Venezuela and Mexico. Coleopterist Bull. 50: $155-160$.
Kistler R.A. 1982. Effects of temperature on six species of seed beetles (Coleoptera: Bruchidae): an ecological perspective. Ann. Entomol. Soc. Am. 75: 266-271.

Kistler R.A. 1995. Influence of temperature on populations within a guild of mesquite bruchids (Coleoptera: Bruchidae). Environ. Entomol. 24: 662-672.

Lonsdale W.M., Harley K.L.S. and Gillett J.D. 1988. Seed bank dynamics in Mimosa pigra, an invasive tropical shrub. J. Appl. Ecol. 25: 963-976.

Louda S.M. 1989. Predation in the dynamics of seed regeneration. In: Leck M.A., Parker V.T. and Simpson R.L. (eds), Ecology of Soil Seed Banks. Academic Press Inc., San Diego, pp. 25-51.

McCoy M.B. and Rodriguez J.M. 1994. Cattail (Typha dominguensis) eradication methods in the restoration of a tropical, seasonal, freshwater marsh. In: Mitsch W.J (ed.), Global Wetlands: Old World and New. Oxford, Elsevier, pp. 469-482.

Midgley J.J. and Bond W.J. 2001. A synthesis of the demography of African acacias. J. Trop. Ecol. 17: 871-886.

Mohnot K. and Chatterji U.N. 1965. Chemico-physiological studies on the imbibition and germination of seeds of Parkinsonia aculeata Linn. Oesterreichische Botanische Zeitschrift 112: 576-585.

Moody M.E. and Mack R.N. 1988. Controlling the spread of plant invasions: The importance of nascent foci. J. Appl. Ecol. 25: 1009-1021.

Ouedraogo P.A., Sou S., Sanon A., Monge J.P., Huignard J., Tran B. and Credland P.F. 1996. Influence of temperature and humidity on populations of Callosobruchus maculatus (Coleoptera: Bruchidae) and its parasitoid Dinarmus basalis (Pteromalidae) in two climatic zones of Burkina Faso. Bull. Entomol. Res. 86: 695-702.

Palmer B. 1996. Parkinsonia. In: Tiver F., Wilson B. and Forno W. (eds), Proceedings of Woody Weeds Workshop, 16-17 March 1996. CSIRO Davies Laboratories, Townsville, pp. 28-29.

Pieterse P.J. and Cairns A.L.P. 1986. The effect of fire on Acacia longifolia seed banks in the south-western Cape. S. Afr. J. Bot. 52: 233-236.

QDNR 1998. Biological control of Parkinsonia with insect species. In: 1997-98 Technical highlights, annual report on weed and pest animal research. Queensland Department of Natural Resources, Coorparoo DC, Queensland, pp. 14-15.

Southgate B.J. 1979. Biology of the Bruchidae. Ann. Rev. Entomol. 24: 449-473.

Teketay D. 1996. Germination ecology of twelve indigenous and eight exotic multipurpose leguminous species from Ethiopia. Forest Ecol. Manage. 80: 209-223.

Traveset A. 1991a. Pre-dispersal seed predation in Central American Acacia farnesiana: factors affecting the abundance of co-occurring bruchid beetles. Oecologia 87: 570-576.

Traveset A. 1991b. Bruchid egg mortality on Acacia farnesiana caused by ants and abiotic factors. Ecol. Entomol. 15: 463-468.

Van der Valk A.G. and Pederson R.L. 1989. Seed banks and the management and restoration of natural vegetation. In: Leck M.A., Parker V.T. and Simpson R.L. (eds), Ecology of Soil Seed Banks. Academic Press Inc, San Diego, pp. 283-305. 
Vaughan C., McCoy M., Fallas J., Chaves H., Barboza G., Wong G., Rau J., Carranza M. and Carbonell M. 1994. Plan de Manejo y Desarrollo del Parque Nacional Palo Verde y Reserva Biologica Lomas Barbudal. Universidad Nacional, Costa Rica.

Vitelli J.S. and Donnelly G. 1995. Parkinsonia. In: March N. (ed.), in North West Queensland. Isa Printing Service, Mount Isa, Australia, pp. 34-35.

Weber E. 2003. Invasive plant species of the world: a reference guide to environmental weeds. CABI Publishing, Wallingford, UK.

Witkowski E.T.F. and Garner R.D. 2000. Spatial distribution of soil seed banks of three African savanna woody species at two contrasting sites. Plant Ecol. 149: 91-106.

Woods W. 1985a. Bruchid seed beetles for control of Parkinsonia aculeata in Australia. In: Delfosse E.S (ed.), Proceedings of the VI International Symposium on Biological Control of Weeds, 19-25 August 1984. Vancouver, Canada, pp. 855-862.

Woods W. 1985b. Initial host specificity testing of the seed beetle Mimosestes ulkei Horn (Coleoptera: Bruchidae), a potential biocontrol agent of Parkinsonia aculeta L. (Leguminosae: Caesalpinaceae). Biological Control Parkinsonia Project, Tucson, Arizona.

Woods W. 1988. The potential for biological control of Parkinsonia aculeata L.: phytophagous insects collected from the U.S.A., Mexico and Costa Rica and the effect of insect damage on the growth and survival of the plant. MSc (Agric.) Thesis, University of Western Australia, Perth.

Wyatt R. 1981. Components of reproductive output in five tropical legumes. Bull. Torrey Bot. Club 108: 67-75.

Yu S.L. and Wang S.P. 1996. Tetrazolium testing for viability of tree seed. In: Bhodthipuks J., Pukittayacamee P., Saelim S., Wang B.S.P and Yu S.L. (eds), Rapid Viability Testing of Tropical Tree Seed, Training Course Proceedings No. 4. ASEAN Forest Tree Seed Centre Project, Muak-Lek, Saraburi, Thailand, pp. 33-39.

Zodape S.T. 1991. The improvement of germination of some forest species by acid scarification. Indian Forester 117: $61-66$. 